\title{
Optimization of cultural conditions for the production of an extra- cellular protease by Pseudomonas species
}

\author{
*Soumya Thrivikraman Vasantha, Abhilash Thankappan Subramanian \\ Department of Applied Microbiology, St. Thomas College, Kerala, India
}

\begin{abstract}
The aim of the study was to identify new sources of protease and a protease producing bacteria was isolated from slaughter house soil and identified as Pseudomonas species. The protease production efficiency of the organism was measured with different environmental and nutritional parameters. Optimization of the fermentation medium for maximum protease production was carried out. The culture condition like temperature, $\mathrm{pH}$, incubation time, carbon and nitrogen sources were optimized. The optimum condition found for protease production was $30^{\circ} \mathrm{C}$ at $\mathrm{pH} 7$ in the medium for 48 hour. Carbon source casein and nitrogen source beef extract stimulated the production of protease. Protease production was higher with immobilized cells. Pseudomonas species can be used profitably for the large scale production of protease to meet the present day demand of the industrial sector.
\end{abstract}

Key Words: Proteolytic enzyme, reeses medium, induction, soyabean meal, casein.

\section{INTRODUCTION}

Biotechnology is gaining ground rapidly due to the various advantages that it offers over conventional chemical processes especially regarding environment and cost involvement. Industrial enzymes represent the heart of biotechnology processes. New and emerging applications have helped drive demand for enzymes and the industry is responding with a continuous stream of innovative products. With increasing emphasis on environmental protection, the use of microbial enzymes has gained considerable attention during the last several years in many industries, including manufacturing of chemicals, textiles, pharmaceuticals, paper, food and agriculture (Mehta et al., 2006).

Proteolytic enzymes are degradative enzymes which catalyze the cleavage of peptide bonds in other proteins. Alkaline proteases, which are referring to proteolytic enzymes which work optimally in

\footnotetext{
*Corresponding Author:

Soumya Thrivikraman Vasantha

Department of Applied Microbiology

St. Thomas College

Kerala, India

E-mail: soumyanair20@gmail.com

Contact No.: 9895496744
}

alkaline $\mathrm{pH}$ are the main enzymes among proteases and constitute $60-65 \%$ of the global industrial enzyme market (Amoozegara et al., 2007). Moreover, they are used in the food industry in meat tenderization processes, peptide synthesis, infant formula preparations, baking and brewing. They are also used in the detergent industry as additives, in pharmaceutical and medical diagnosis as well as in the textile industry in the process of dehairing and leather processing (Tari et al., 2006). Owing to its potential applications and desirable properties, plenty of research is being done on proteases. The preferred sources of proteases are microbes because of their rapid growth and the ease with which they can be genetically manipulated to generate new enzymes with altered properties and are currently being utilized by the detergent industry e.g. Serine proteases produced by Bacillus strains (Rao et al., 1998).

Isolation and identification of promising strains, characterization of enzymes and optimization of products is an ongoing process. Proteases producing bacteria are widely isolated from soil with high protein content (Sing et al., 2001). Genus Pseudomonas a gram-negative bacterium that predominantly produces alkaline proteolytic enzymes and the proteases has been purified (Jellouli et al., 2008). 
The production medium usually used is Reeses medium. Microbial proteases are produced from high yielding strains by fermentation under controlled conditions in surface or submerged culture (Barret et al., 2003). High concentration of salts and chemicals such as glycerol often increase general enzyme stability and product shelf life (Aroma, 1964). The $\mathrm{pH}$ of the liquid should be adjusted to optimize stability. Designing of media is required to optimize induction and minimize the chances of repression. It has been reported that $B$. licheniformis produces has very narrow zones of hydrolysis on casein-agar despite giving very good protease production in submerged cultures.

Most published media for production of proteases contain nitrogen sources such as soyabean meal, casein, corn-steep powder or liquor, solubles, brewer's yeast and carbohydrate sources such as starch, ground barley or lactose. It is also seen that free amino acids repress protease production. Proteases of some enzymes like Pseudomonas wallophilie are constitutive. It has been reported that peptides or proteins induce protease synthesis in a number of microorganisms. Casein assay is the most commonly used assay procedure for protease activity. It involves TCA precipitation of the undigested substrate followed by photometric quantification of the released aromatic amino acid, using L-tyrosine as standard. Due to their compact conformation, native proteins are generally not very susceptible to degradation by proteases. Protein substrate for proteases is mostly casein which must be completely soluble in buffer. Casein precipitates below $\mathrm{pH}$ 6, so it is used at neutral to alkaline $\mathrm{pH}$.

In commercial practice, the optimization of medium composition is done to maintain a balance between the various medium components, thus minimizing the amount of unutilized components at the end of the process. In addition, no defined medium has been established for the optimum production of protease from different microbial sources. Each organism or strain has its own special conditions for maximum enzyme production (Banerjee et al., 1999). Immobilization of proteases to improve their performance has also been done. It is reported that the immobilized enzymes have retained $90 \%$ of the total activity compared with the soluble enzyme. Also temperature stability of the immobilized protease compared to the soluble enzyme has showed $15-20 \%$ increase as indicated by its inactivation pattern. Upon repeated use, the entrapped enzyme retained $83 \%$ of its initial activity after 6 cycles (Wilson et al., 1992). A novel use of alkaline proteases is its proposed usefulness in detection of Pseudomonas aeroginosa in ELISA tests. Most of the alkaline proteases so far reported are thermostable, $\mathrm{pH}$ tolerant and compatible with commercial laundry detergents (Anwar et al., 2000). In some cases, purified and characterized proteases were found to be superior to endogenous proteases already present in commercial laundry detergents (Kumar et al., 2002).

The first objective of the present work was to identify new sources of alkaline proteases eg: Soil sample of the slaughter house waste site which is rich in organic waste was selected for Screening of microbial isolate that can produce alkaline protease. Secondly Selection of Pseudomonas strain with highest enzyme activity as test strain and physicochemical conditions such as temperature, $\mathrm{pH}$ and incubation time were optimized for the best enzyme production.

\section{MATERIALS AND METHODS}

Screening of different soil samples for protease producing organisms

Different soil samples were collected from different areas. Those areas were selected on the basis of the waste debris they contain and were mainly protein rich. Samples were collected from different areas like fish market, slaughter house and dairy farm. $10 \mathrm{~g}$ of soil was weighed and added to $250 \mathrm{ml}$ Reese's medium in conical flasks and were incubated at $29^{\circ} \mathrm{C}$ for 7 days. Cultures were then plated on nutrient agar with $0.4 \%$ gelatin and were incubated at $30^{\circ} \mathrm{C}$ for 24 hours and were flooded with $1 \%$ tannic acid. Protease producing colonies were identified on the basis of development of halos around the colonies on addition of $1 \%$ tannic acid. Samples were also inoculated to milk agar using spread plate technique, incubated at $37^{\circ} \mathrm{C}$ for 24 hours and then observed for zones of casein hydrolysis around the colonies. Selected colonies were streaked on to nutrient agar slants, incubated and then stored at $4^{\circ} \mathrm{C}$. 
Table 1: Protease production by Pseudomonas sps.

\begin{tabular}{cc}
\hline Isolate Number & Enzyme activity (U/ml)* \\
\hline $\mathrm{P}_{1}$ & 19.6 \\
$\mathrm{P}_{2}$ & 2 \\
$\mathrm{P}_{3}$ & 11.6 \\
$\mathrm{P}_{4}$ & 10 \\
$\mathrm{P}_{5}$ & 20.4 \\
$\mathrm{P}_{6}$ & 3.6 \\
$\mathrm{P}_{7}$ & 14.4 \\
$\mathrm{P}_{8}$ & 23.2 \\
$\mathrm{P}_{9}$ & 3.2 \\
$\mathrm{P}_{10}$ & 4 \\
$\mathrm{P}_{11}$ & 16 \\
$\mathrm{P}_{12}$ & 1.2 \\
$\mathrm{P}_{13}$ & 20.4 \\
$\mathrm{P}_{14}$ & 1.5 \\
$\mathrm{P}_{15}$ & 8.4 \\
$\mathrm{P}_{16}$ & 17.2 \\
$\mathrm{P}_{17}$ & 5.2 \\
$\mathrm{P}_{18}$ & 20.8 \\
$\mathrm{P}_{19}$ & 12 \\
$\mathrm{P}_{20}$ & 6 \\
B. licheniformis NCIM 2042 & 18.8 \\
\hline
\end{tabular}

${ }^{*}$ One unit of enzyme activity represents the amount of enzyme that liberates one $\mu \mathrm{g}$ of tyrosine $/ \mathrm{ml} /$ minute

\section{Identification of pseudomonas $s p$}

Morphological characterization

Macroscopic and microscopic characterization were carried out based on colony, pigmentation, gram stain \& hanging drop method.

\section{Biochemical tests}

Biochemical characterization was carried out based on oxidase test, catalase test, nitrate reductase, ornithine decarboxylase, tween 20 hydrolysis, IMViC tests, utilization of glucose, lactose, arabinose, gelatin-liquefaction and starch hydrolysis test.

\section{Estimation of enzyme activity of isolates \\ Enzyme Production}

Pure culture of each isolate was inoculated into the production medium and incubated at $30^{\circ} \mathrm{C}$ for $48-72$ hours on shaker. At the end of fermentation period, the culture medium was centrifuged at $10000 \mathrm{rpm}$ for 15 minutes to obtain the crude extract which was used as enzyme source and the protease activity was assayed.

\section{Protease assay}

Different aliquots of standard solution (tyrosine $200 \mathrm{~g} / \mathrm{ml}$ ) ranging from $0.2-1 \mathrm{ml}$ were pipette in
Table 2: Optimization of production media for various temperatures.

\begin{tabular}{ccc}
\hline Sl. No. & Temperature $\left({ }^{\circ} \mathbf{C}\right)$ & Activity $(\mathbf{U} / \mathbf{m l})$ \\
\hline 1 & 30 & 27.2 \\
2 & 40 & 24.3 \\
3 & 50 & 20.8 \\
4 & 60 & 16.24 \\
5 & 70 & 7.6 \\
6 & 80 & 5.01 \\
\hline
\end{tabular}

different test tubes and the volume were made up to $1 \mathrm{ml}$ with distilled water. $5 \mathrm{ml}$ of alkaline reagent $\left(0.44 \mathrm{M} \mathrm{Na}_{2} \mathrm{CO}_{3}\right)$ was added to all the tubes. They were incubated at room temperature for 10 minutes. $0.5 \mathrm{ml}$ of FCR was added to all the tubes and incubated at room temperature for 20 minutes. OD was measured at $660 \mathrm{~nm}$ against a suitable blank containing distilled water, alkaline reagent and FCR. A standard graph was plotted by taking conc. of standard along $\mathrm{X}$-axis and $\mathrm{OD}$ value along $\mathrm{Y}$-axis.

$0.5 \mathrm{ml}$ of $2 \%$ casein (in $0.2 \mathrm{M}$ carbonate buffer of $\mathrm{pH}$ 10.0) solution was added to test tubes labeled test and control. $0.5 \mathrm{ml}$ of enzyme extract was added to the test and incubated at $40^{\circ} \mathrm{C}$ for 10 minutes. After incubation, the reaction was terminated by the addition of $1 \mathrm{ml} 10 \%$ TCA and $0.5 \mathrm{ml}$ of heat killed enzyme was added to the control tube. It was centrifuged at $1000 \mathrm{rpm}$ for 10 minutes and $1 \mathrm{ml}$ of supernatant from test and control tubes were transferred to fresh tubes. To $1 \mathrm{ml}$ of supernatant, $5 \mathrm{ml}$ of $0.44 \mathrm{M} \mathrm{Na}_{2} \mathrm{CO}_{3}$ and $1 \mathrm{ml}$ of FCR were added and the tubes were incubated at room temp for $30^{\circ} \mathrm{C}$ in dark. The OD was measured at $660 \mathrm{~nm}$. One unit of enzyme activity was defined as the amount of enzyme that released one $\mu \mathrm{g}$ tyrosine $/ \mathrm{ml} / \mathrm{min}$.

Estimation of protein in enzyme source by Bradford dye binding method

$10,30,50,70$ and $90 \mu \mathrm{l}$ of standard protein solution (BSA- $1 \mathrm{mg} / \mathrm{ml}$ ) and $50 \mu \mathrm{l}$ of enzyme solution were pipette out in a series of test tubes and the volume was made up to $100 \mu \mathrm{l}$ with glacial acetic acid solution served as blank. $5 \mathrm{ml}$ of Bradford reagent was added and mixed thoroughly. The absorbance was measured at $595 \mathrm{~nm}$, within half a have against the blank. A standard graph was plotted by taking concentration of standard along $\mathrm{X}$-axis and $\mathrm{OD}$ 
Table 3: Optimization of production media for various $\mathrm{pH}$.

\begin{tabular}{ccc}
\hline Sl. No. & pH & Activity (U/ml) \\
\hline 1 & 4.0 & 1.42 \\
2 & 5.0 & 2.0 \\
3 & 7.0 & 27.2 \\
4 & 9.0 & 16.8 \\
5 & 10 & 4.2 \\
\hline
\end{tabular}

along Y-axis. The amount of protein in the enzyme solution was calculated.

\section{Selection of test strain and comparison with that of standard strain}

The enzyme activity of all the isolated Pseudomonas strain was determined and the strains showing the highest activity was selected as the test strain. The activity of the test strain was compared with that of standard strain.

\section{Optimization of Cultural conditions \\ Optimization of temperature}

The production medium (pH7) was inoculated with the test strain and incubated at different temperatures $\left(30^{\circ} \mathrm{C}, 40^{\circ} \mathrm{C}, 50^{\circ} \mathrm{C}, 70^{\circ} \mathrm{C}\right.$ and $\left.80^{\circ} \mathrm{C}\right)$ in a shaking incubator for 48-72 hrs with 65 revolutions/minute.

\section{Optimization of medium $\mathrm{pH}$}

The $\mathrm{pH}$ of the medium was optimized by varying the $\mathrm{pH}$ of the medium $(\mathrm{pH} \mathrm{10,9,7}$ and 5, 4) keeping the temperature $\left(30^{\circ} \mathrm{C}\right)$ and incubation period $(48$ hrs) constant.

\section{Optimization of incubation period}

It was determined by subjecting the inoculum to varying incubation periods such a $24,32,48$ and 72 hours while keeping other parameters such as $\mathrm{pH}$ and temperature constant.

Effect of different Carbon and Nitrogen sources on Protease Production

The best carbon and nitrogen source for protein production was determined by substituting different carbon sources such as skimmed milk, casein, lactose and maltose for glucose and different nitrogen sources such as beef extract, glycine, soyabean and tryptone were substituted for peptone, and the activity of the enzyme was determined spectrophotometrically. During this process, the
Table 4: Optimization of production media for various Incubation periods.

\begin{tabular}{ccc}
\hline Sl. No. & Incubation period (h) & Activity (U/ml) \\
\hline 1 & 12 & 1.14 \\
2 & 24 & 1.6 \\
3 & 48 & 27.2 \\
4 & 72 & 19.6 \\
5 & 96 & 6.42 \\
\hline
\end{tabular}

other conditions such as temperature, $\mathrm{pH}$ and incubation periods were kept constant.

\section{Effect of mutation}

The test strain was inoculated into nutrient both which was poured on to sterile Petri plates and were kept open and exposed to UV for time periods ranging from 10, 20, 30, 40 and 60 minutes. They were then streaked on to nutrient agar plates and incubated for $48 \mathrm{hrs}$ and $30^{\circ} \mathrm{C}$. A single colony from each was inoculated into production medium and was incubated and assayed for enzyme activity.

\section{Effect of immobilization}

Cells from a 24 hour culture were mixed with sodium alginate solution. It was then dropped into calcium chloride solution using a pipette to form calcium alginate beads with cells entrapped. The beads were kept for solidification. They were then washed 3 or 4 times with distilled water. $20-25$ beads were added to the production media and was incubated for $48 \mathrm{hrs}$ at $40^{\circ} \mathrm{C}$ and assayed for enzyme activity.

\section{RESULTS AND DISCUSSION}

Out of 6 samples collected, 42 protease producing organisms were isolated based on the reaction shown in milk agar and nutrient-gelatin agar. From 42 isolates, 20 were identified as Pseudomonas sps. $\left(\mathrm{P}_{1}\right.$ - $\left.\mathrm{P}_{20}\right)$ based on colony morphology, Gram stain and biochemical reactions. Protease activity was determined for these 20 isolates and the results were depicted in Table1.Strains from slaughter house soil showed higher activity compared to isolates from other sources. Selected strain P8 showed highest enzyme activity among the isolates and was selected as test strain. The test strain showed more activity $(23.2 \mathrm{U} / \mathrm{ml})$ than the standard strain $(18.8 \mathrm{U} / \mathrm{ml})$ i.e. Bacillus licheniformis NCIM2042. 
Table 5: Optimization of production media for various carbon sources.

\begin{tabular}{ccc}
\hline Sl. No. & Carbon source & Activity (U/ml) \\
\hline 1 & Skim milk & 16.8 \\
2 & Casein & 20.8 \\
3 & Maltose & 14.8 \\
\hline
\end{tabular}

Table 6: Optimization of production media for various nitrogen sources.

\begin{tabular}{ccc}
\hline Sl. No. & Nitrogen sources & Activity (U/ml) \\
\hline 1 & Beef extract & 25.2 \\
2 & Glycine & 14.6 \\
3 & Soyabean & 19.6 \\
& Tryptone & 19.2 \\
\hline
\end{tabular}

Protease production at different temperature was examined keeping other conditions constant, the results were depicted in table 2. Maximum production of protease was obtained at $30^{\circ} \mathrm{C}$. It was capable of producing protease in the range of $30^{\circ}-50^{\circ} \mathrm{C}$. However, increase in temperature beyond $50^{\circ} \mathrm{C}$ led to decline in production of enzyme proving that temperature plays a major role in protease production. The results are in accordance with Fujiwara and yamamoto who reported that protease activity was high at $30^{\circ} \mathrm{C}$ for Bacillus species. The $\mathrm{pH}$ of the culture strongly affects many enzymatic processes and transport of compounds across the cell membrane. Highest protease activity was recorded at $\mathrm{pH}$ 7 ; the results were depicted in table 3 . By growing the culture at optimum $\mathrm{pH}$ and temperature, the activity of protease was estimated at different intervals of growth. Protease production was found to be highest at $48 \mathrm{~h}$ (table 4). The enzyme activity gradually decreases from 72 to $96 \mathrm{hrs}$.

The addition of carbon source in the form of either monosaccharides or polysaccharides could influence the production of enzyme (Sudharshan et al., 2007). Among the carbon sources casein was found to support maximum protease production (table 5). Among the nitrogen sources, beef extract produced maximum protease and second one was soyabean meal (table 6). This finding is in agreement with finding of Sinha and Satyanarayana (1999) who found out that medium enriched with soyabean was a better nitrogen source for protease production.
Microbial products are usually produced either by free or immobilized cells. Cell immobilization is one of the common techniques for increasing the overall cell concentration and productivity. Protease production was higher with immobilized cells than that of free cells.

\section{CONCLUSION}

The production of protease was enhanced by the optimization of cultural conditions. Pseudomonas sp. can be used profitably for large scale production of protease to meet the present day demand of the industrial sector.

\section{REFERENCES}

Adesh Kumar, Archana Sachdev, S.D. Balasubramanyam (2002) Optimization of conditions for production of alkaline protease from species of Bacillus and Psendomonas, Indian Journal of microbiology vol. 42, Sc.

Amoozegara, M.A., Fatemia, A.Z., Ksrbalaei-Heidarib, H.R. and Razavic, M.R.R. (2007). Production of extracelluylar alkaline protease from a newly isolated, moderately halophilie Salinivibrio sp. Strain AF-2004. Microbiol, Res. 162: 369-377 [DOI]

Anwar, A., and Saleemnudden, M. (2000) Alkaline protease from Spilosoma oblique : potential application in bioformulation. Biotechnology and Applied Chemistry April, vol. 31, no.2, pg 85-89.

Aroma, K. (1964) Microbial Enzyme production in Global aspects of Applied Microbiology. John Wiley and Sons, Ine. New York pg 277-294.

Banerjee, U.C., Sani, R.K., Azmi, N and Soni R. (1999) Themostable alkaline proteases from Bacilli braves and into characterization as a laundry additive process Biochemistry October, vol 35 no.1. pg 213-219.

Barret, A.J., Rawlings, N.D. and Woessner, J.F. 2003. The Handbook of Proteolytic Enzymes, $2^{\text {nd }}$ ed. Academic Press.

Fujiwara, N., Yamamoto, K. (1987). Production of alkaline protease in a liw cost medium by alkalophutlic Bacillus Sp.and properties of the enzymes. J .Ferment Techno. 65: 345-348. [DOI]

Harwood, C.R., Cranenburgh, R. (2008) Bacillus protein secretion: an unfolding story. Trends Microbiol, vol. 16, no. 2, pp. 73-79. [DOI] PMid:18182292

Jellouli, K., Bayoudh, A., Manni L., Agrebi R. and Nasri M.(2008) Purification,biochemical and molecular characterization of a metalloprotease from Pseudomonas aeruginosa MN7 grown on shrimp wastes. Appl Microbiol Biotechnol, vol. 79, pp. 989-99. [DOI] PMid:18512057 
Mehta, V.J., Thumar, J.T. and Singh, S.P. (2006). Production of alkaline protease from alkaliphilic actinomycetes. Bioresour. Technol. 97: 1650-1654 [DOI] PMid:16203132

Md. Javed Foysal., Gokul Chandra Biswas, Md. Jahir Raihan. PCR based detection of gyrB2 gene from Pseudomonas sp. affected human clinical isolates. International Current Pharmaceutical Journal 2012, 1(9): 235-238

Rao, M.B., Tanksale, A.M., Ghatge, M. S. and Deshpande V.V. (1998). Molecular and biotechnological aspects of microbial protease. Microbiol. Mol. Biol. Rev, vol.62, no. 3, pp. 597-635. PMid:9729602 PMCid:98927

Sing, J., Batra, N. and Sobti, R.C .(2001) Serine alkaline protease from a newly isolated Bacillus sp. SSR, Process Biochemistry 36; pg. 781-785. [DOI]
Sinha, N., Satyanarayana, T. (1999) . Alkaline Protease production by thermophile Bacillus licheniformis. Enzyme Microbiol.Technol. 8: 370-372

Sudharshan, R.K., Dutt, L. ,Nayyar, R. (2007). A highly thermostable and alkaline amylase from a Bacillus.sp. PN5. BIOresour. Technol.21:25-29

Tari, C., Genckal, H. and Tokatli, F. (2006). Optimization of growth medium using a statistical approach for the production of alkaline proteasefrom a newly isolated Bacillus sp. L 21. Proc. Biochem. 41: 659-665. [DOI]

Wilson, S.A, young, O.A., Coolbear, T and Daniel, R.M. (1992) The use of protease from extremes thermopiles for meet tenderization, meet sci, 32; 93-103. 